\title{
Postprandial metabolic responses of serum calcium, parathyroid hormone and C-telopeptide of type I collagen to three doses of calcium delivered in milk
}

\author{
Marlena C. Kruger ${ }^{1}$, Pamela R. von Hurst ${ }^{2}$, Christine L. Booth ${ }^{1}$, Barbara Kuhn-Sherlock ${ }^{3}$, \\ Joanne M. Todd ${ }^{4}$ and Linda M. Schollum ${ }^{3}$ \\ ${ }^{1}$ Institute of Food, Nutrition and Human Health, Massey University, Private Bag 11222, Palmerston North, New Zealand \\ ${ }^{2}$ Institute of Food, Nutrition and Human Health, Massey University, Private Bag 102 904, North Shore Mail Centre, Auckland, New Zealand \\ ${ }^{3}$ Fonterra Research and Development Centre, Private 11029, Palmerston North, 4442, New Zealand \\ ${ }^{4}$ Fonterra Co-Operative Group Ltd, Private Bag 92032, 9 Princes Street, Auckland, New Zealand
}

(Received 13 August 2013 - Final revision received 23 December 2013 - Accepted 14 January 2014)

Journal of Nutritional Science (2014), vol. 3, e6, page 1 of 9

doi:10.1017/jns.2014.2

Abstract

Acute doses of Ca rapidly increase serum $\mathrm{Ca}$ and reduce bone resorption concomitant with a reduction in serum parathyroid hormone (PTH) levels. The physiological response to a dose of $\mathrm{Ca}$ in milk and to a $\mathrm{Ca}$ salt may be different. The present study investigated $\mathrm{Ca}$ absorption patterns with increasing levels of fortification in milk, and the response to one dose of a Ca salt. A group of twenty-eight Asian women aged 20-45 years volunteered to attend the laboratory over several weeks. The fasted volunteers were randomised to one of three experimental drinks: $200 \mathrm{ml}$ skimmed milk containing 250,500 or $1000 \mathrm{mg}$ Ca. A subgroup of seven volunteers also received a calcium gluconate/carbonate salt containing $1000 \mathrm{mg}$ Ca in $200 \mathrm{ml}$ water. Serial blood samples and urine were collected for $5 \mathrm{~h}$ from baseline. Different doses of $\mathrm{Ca}$ in milk resulted in a graded response in serum corrected $\mathrm{Ca}$, PTH and C-telopeptide of type I collagen (CTx) but not ionised Ca. Serum Ca increased in response to all milk drinks and from 2 to $5 \mathrm{~h}$ the blood Ca levels were significantly different for the 250 and $1000 \mathrm{mg}$ doses, as was the integrated response between the loads. The PTH response to the two higher doses was significantly more than following the $250 \mathrm{mg}$ dose. The integrated response for CTx and urinary Ca between all three doses of Ca in milk was significantly different. A dose of $\mathrm{Ca}$ salt elicited a more immediate response reaching a plateau faster, and declining faster to baseline. Fortified milk is a safe matrix for delivering larger doses of $\mathrm{Ca}$.

Key words: Calcium absorption: Milk: Asian women: Parathyroid hormone: Urinary calcium: C-telopeptide of type I collagen

Adequate $\mathrm{Ca}$ intake is important to achieve optimal peak bone mass and prevent or reduce bone loss with ageing. Obtaining the recommended daily $\mathrm{Ca}$ allowance from foods is recommended, as other bioactives could be present that may enhance the health benefits of the food. Milk can be fortified with a $\mathrm{Ca}$ salt to increase the amount of $\mathrm{Ca}$ delivered per dose of milk and Ca from milk is usually well absorbed.

An acute oral dose of a Ca salt rapidly increases serum corrected, i.e. Ca corrected for albumin, as well as ionised $\mathrm{Ca}$ and reduces bone resorption (serum C-telopeptide of type I collagen; CTx) with a concomitant reduction in parathyroid hormone (PTH) levels ${ }^{(1-4)}$. Fractional $\mathrm{Ca}$ absorption is an inverse function of load size ${ }^{(5-7)}$. Measuring the response to three doses of a Ca salt, using urinary $\mathrm{Ca}$ and serum $\mathrm{Ca}$ concentrations, indicated that there is a plateau in the postprandial response at a dose of $500 \mathrm{mg}$ with a slight increase in the response to a dose of $1000 \mathrm{mg}^{(8,9)}$. Heaney et al. ${ }^{(7)}$ reported that the $\mathrm{Ca}$ response slopes for a single dose of $1 \mathrm{~g}$ calcium

Abbreviations: CTx, C-telopeptide of type I collagen; PTH, parathyroid hormone.

* Corresponding author: Dr Marlena C. Kruger, email m.c.kruger@massey.ac.nz 
carbonate $v$. divided doses over several hours were similar up to approximately $5 \mathrm{~h}$ and that absorption was capacity limited even when the doses were divided. In addition, Karkkainen et $a l^{(10)}$ reported a significant difference between the changes in serum ionised $\mathrm{Ca}$ induced by a dose of $250 \mathrm{mg}$ compared with $1000 \mathrm{mg}$ Ca.

An acute dose of $\mathrm{Ca}$ in milk, however, results in a slower change in serum ionised $\mathrm{Ca}$ in comparison with a similar dose of a Ca salt ${ }^{(11-13)}$. Karkkainen et al. ${ }^{(14)}$ compared the postprandial $\mathrm{Ca}$ response from four different foods including milk, and showed that ingestion of $400 \mathrm{mg}$ Ca in milk caused a significantly smaller increase in serum ionised Ca compared with the control $\mathrm{Ca}$ salt. Other studies report similar findings when a $\mathrm{Ca}$ salt was compared with milk or Ca-fortified milk $^{(11)}$, confirming that the matrix in which the $\mathrm{Ca}$ is delivered could therefore affect the rate of appearance and the rise in serum $\mathrm{Ca}$.

More recent studies using milk as the vehicle showed that an acute dose of Ca (1200 mg per dose) in milk also suppresses both PTH levels and bone resorption in adult men and women ${ }^{(11,15,16)}$. When milk fortified with milk Ca was compared with milk fortified with calcium carbonate at a single dose of $1200 \mathrm{mg} \mathrm{Ca}$, the calcium carbonate-fortified milk suppressed PTH and bone resorption significantly more than the milk fortified with milk $\mathrm{Ca}^{(11,13)}$.

In longer-term studies, Kruger et al. ${ }^{(17,18)}$ showed that the reduction in PTH and CTx resulting from supplementing pre- and postmenopausal women with $1200 \mathrm{mg}$ Ca per d as fortified milk was maintained over the 12-16 weeks of the interventions.

The objectives of the present study were to assess the acute postprandial physiological response to a series of different $\mathrm{Ca}$ loads in a milk-based drink, by measuring serum PTH, serum CTx, serum corrected and ionised $\mathrm{Ca}$ and urinary $\mathrm{Ca}$ excretion over a $5 \mathrm{~h}$ period. A secondary objective was to compare the postprandial response to a similar load of $\mathrm{Ca}$ as a salt in water or as a salt in milk.

\section{Methods}

The present study was conducted according to the guidelines laid down in the Declaration of Helsinki and all procedures involving human subjects were approved by the Massey University Human Ethics Committee (Southern A; approval no. 10/65). Written informed consent was obtained from all subjects. The study was run as a single-blinded randomised controlled trial.

\section{Experimental subjects}

A total of twenty-eight Asian female volunteers aged 20-45 years, living in Auckland or Palmerston North, New Zealand, were recruited from the community through the local newspapers and Massey University Campus advertising. Inclusion criteria were aged $20-45$ years, the ability to tolerate a glass of milk, and not taking Ca supplements or vitamin D supplements, or, if so, agreeing to stop these for 4 weeks before entering the trial. Other exclusion criteria were more than three units of alcohol per d, smoking, endocrine disease, diagnosis of any form of cancer, vascular disease or diabetes mellitus. The trial was preceded by a health screen of liver and kidney function and haematology.

\section{Anthropometry}

Body weight was measured using a digital balance (model BWB-627-A; Tanita Corporation) to the nearest $0.1 \mathrm{~kg}$, and standing height was measured using a stadiometer (Institute of Fundamental Sciences, Engineering Services Workshop, Massey University) to the nearest $0 \cdot 1 \mathrm{~cm}$. Bone mineral density of the total hip, femoral neck and lumbar spine was measured using a Hologic Discovery A densitometer.

\section{Food intake}

Food intake was assessed using a $3 \mathrm{~d}$ recall at baseline. Dietary macro- and micronutrient composition was calculated from the New Zealand Food Composition Table, accessed using nutrient analysis software (FOODworks 2009; Xyris software (Australia) Pty Ltd).

\section{Procedures}

Volunteers attended the Human Research Laboratories at Massey University campuses at Palmerston North or Albany on three occasions at least 1 week apart, for $7 \mathrm{~h}$ at each occasion. They were randomised by the study nurse (computergenerated random numbers) to ingest one of three milk drinks at each occasion. The volunteers arrived in the laboratory at approximately 08.30 hours after fasting since 21.00 hours the previous night. The volunteers were asked to empty their bladders. An indwelling intravenous cannula was placed in an antecubital vein and kept patent using normal saline. Baseline blood samples were taken shortly after the cannula was sited. The volunteers were then given one of the three test drinks, which they consumed within $15 \mathrm{~min}$. In order to avoid any effect of circadian rhythm in the measurements, the volunteers were asked to begin consuming the drinks between 09.00 and 09.30 hours; the actual time was recorded and referred to as time zero. The blood sampling times were staggered so that the time from taking the test drink to the time that the first blood sample was taken was exactly the same for each participant.

The milk drinks contained either $250 \mathrm{mg}$ Ca (20.1 g skimmed milk powder; NZMPтм Fonterra Ingredients Ltd), $500 \mathrm{mg} \quad \mathrm{Ca} \quad(30 \mathrm{~g}$ fortified reduced fat milk powder; Anlene $^{\mathrm{TM}}$, Fonterra Brands Ltd) or $1000 \mathrm{mg}$ Ca (30 g fortified reduced fat milk powder; Fonterra Brands Ltd) in $200 \mathrm{ml}$ of deionised water followed by another $50 \mathrm{ml}$ to wash out the container of any residual milk drink. Blood samples $(20 \mathrm{ml})$ were collected every $1 \mathrm{~h}$, and urine was collected every $2 \mathrm{~h}$ period for $6 \mathrm{~h}$. The volunteers were permitted $100 \mathrm{ml}$ water every $1 \mathrm{~h}$.

The blood samples were kept cold until they were spun at $2000 \mathrm{~g}$ for $10 \mathrm{~min}$ at $4^{\circ} \mathrm{C}$ and the supernatant fraction was sampled and stored frozen until analysis. Urine was collected 
after the first morning void until time zero, and was then collected from baseline every $2 \mathrm{~h}$ for $6 \mathrm{~h}$ from the start of consuming the drink. The urine volumes were measured, and a representative sample was then stored frozen until analysis.

The volunteers were given two plain biscuits after $2 \mathrm{~h}$ and a light lunch after $4 \mathrm{~h}$, comprising two slices of wholemeal bread, thinly spread with sunflower margarine, and $130 \mathrm{~g}$ canned peaches in syrup. The composition of the food that was consumed during the day is shown in Table 1.

A subgroup of seven women attended the human studies laboratory in Palmerston North twice more. On these occasions they received either the fortified milk with $1000 \mathrm{mg} \mathrm{Ca}$ or $1000 \mathrm{mg} \mathrm{Ca}$ from a tablet containing $2 \cdot 3 \mathrm{~g}$ calcium lactate gluconate and $1.8 \mathrm{~g}$ calcium carbonate (Calsource Ca1000; Novartis) in $200 \mathrm{ml}$ water in a random order. The experimental procedure was the same as above.

\section{Primary outcome measures}

Serum and urinary Ca was measured by spectrophotometry using the Arsenazo-III dye reaction with an Abbott c8000 analyser (Abbott Laboratories). P was measured using the phosphomolybdate method, and albumin was measured using the bromcresol green method on the Abbott c8000 analyser. Serum $\mathrm{Ca}$ was corrected for albumin. Ionised $\mathrm{Ca}$ was measured using a $\mathrm{Ca}$ electrode (ion sensitive) and a potentiometric method using the Nernst equation. All the above analyses were performed by Medlab Central, Palmerston North, or Lab Plus, Auckland, New Zealand.

Serum 25-hydroxyvitamin D was measured using isotopedilution liquid chromatography-tandem $\mathrm{MS}^{(19)}$. The $\mathrm{CV}$ for the vitamin D assays ranged from 6.8 to $10.2 \%$. Serum cross-linked CTx (CrossLaps) and PTH were measured by electrochemiluminescence immunoassays using the Roche Elecsys 2010 system and commercially available kits (Roche Diagnostics, GmbH). For CTx the uncertainty of measurement was between 4.6 and $5.3 \%$ depending on the level of CTx, and for PTH was between 3.1 and $5.6 \%$ depending on the level of PTH measured. These assays were performed by Canterbury Health Laboratories, an accredited clinical facility.

\section{Statistical analyses}

Outcome variables (AUC, raw data and difference from baseline) were analysed using linear mixed-model ANOVA (Proc

Table 1. Nutrient composition of the single meal consumed during each $1 \mathrm{~d}$ study

\begin{tabular}{lcc}
\hline Nutrient & Amount & \% Energy intake \\
\hline Energy $(\mathrm{kJ})$ & 1510 & $\mathrm{~N} / \mathrm{A}$ \\
Carbohydrate $(\mathrm{g})$ & 64.1 & 68 \\
Protein $(\mathrm{g})$ & $8 \cdot 2$ & 9.2 \\
Fat $(\mathrm{g})$ & 8.5 & $20 \cdot 8$ \\
Ca $(\mathrm{mg})$ & $35 \cdot 2$ & $\mathrm{~N} / \mathrm{A}$ \\
Vitamin D $(\mu \mathrm{g})$ & 0.31 & $\mathrm{~N} / \mathrm{A}$ \\
\hline
\end{tabular}

$\mathrm{N} / \mathrm{A}$, not applicable.
Mixed, SAS version 9.1; SAS Institute Inc.). Integrated AUC for the change from baseline ( 1 to $5 \mathrm{~h}$ ) were calculated for each serum measurement. The model included the effects of subject, treatment, visit and baseline concentration.

For the repeated-measures analysis, subject, treatment, visit and time were included in the procedure, in addition to the treatment $\times$ time interaction which addresses whether the trajectory over time during the visit differs between treatments (treatment $\times$ time). The model for difference from baseline included the result at baseline as a covariate, but only five time points (1, 2, 3, 4 and $5 \mathrm{~h})$.

Where the linear mixed-model ANOVA was significant, Tukey's post hoc analysis was used for comparisons between treatments. Missing data were assumed to be missing at random and no data imputation was performed. Statistical significance was set at a level of $P \leq 0 \cdot 05$. Efficacy endpoints (AUC, difference from baseline, or raw data) are presented as least-squares means (lsmeans) and $95 \%$ CI.

\section{Results}

\section{Physical characteristics of the volunteers}

A total of twenty-eight women of Asian ethnicity were recruited in Palmerston North (n 13) and Auckland ( $n$ 15). The majority of the women reported their ethnicity as Chinese (n 19), together with five Malays, three from Thailand and one from the Philippines. Their baseline characteristics and bone density results are shown in Table 2 .

\section{Biochemical analysis}

The baseline biochemical measurements are presented in Table 2. Vitamin D status was negatively associated with baseline PTH levels $(r-0.448 ; P \leq 0.001)$ and with baseline CTx levels $(r 0 \cdot 219 ; P=0 \cdot 046)$. Baseline PTH levels were significantly correlated with baseline serum corrected $\mathrm{Ca}(r-0 \cdot 373$; $P<0 \cdot 05)$ and baseline CTx $(r-0.217 ; P<0 \cdot 047)$. Dietary $\mathrm{Ca}$ intake was associated with baseline PTH $(r-0.243 ; P<$ $0.025)$, change in urinary $\mathrm{Ca}(r-0.266 ; P<0.015)$, change in PTH $(r$ 0.365; $P<0.001)$ and change in CTx $(r 0.224 ; P<$ 0.04). Using $50 \mathrm{nmol} / 1$ as the level for vitamin $D$ adequacy, about $21 \%$ of the women were vitamin D deficient, $50 \%$ insufficient and $28 \%$ had adequate vitamin D levels.

\section{Dietary analysis}

Dietary intake was calculated from a $3 \mathrm{~d}$ estimated food diary completed by the subjects, and relevant average intakes are listed in Table 3. The mean Ca intake was $587 \mathrm{mg} / \mathrm{d}$, with a range between 189 and $1440 \mathrm{mg}$.

\section{Serum calcium}

The level of $\mathrm{Ca}$ in the drink combined with the influence of time (drink $\times$ time) had a significant effect on serum total $\mathrm{Ca}$ adjusted for albumin $(P<0 \cdot 005)$. Serum $\mathrm{Ca}$ increased in response to all milk drinks in the first $3 \mathrm{~h}$ following 
Table 2. Baseline characteristics of the study population (Mean values, standard deviations and ranges; $n$ 28)

\begin{tabular}{|c|c|c|c|}
\hline & Mean & SD & Range \\
\hline Age (years) & $26 \cdot 7$ & 4.3 & 20 to 37 \\
\hline BMI $\left(\mathrm{kg} / \mathrm{m}^{2}\right)$ & $21 \cdot 2$ & $2 \cdot 3$ & $16 \cdot 7$ to $26 \cdot 8$ \\
\hline Lumbar spine BMD $\left(\mathrm{g} / \mathrm{cm}^{2}\right)$ & 0.979 & 0.106 & 0.733 to 1.206 \\
\hline Lumbar spine $Z$ score & -0.5465 & 0.966 & -2.8 to 1.5 \\
\hline Femoral neck BMD $\left(\mathrm{g} / \mathrm{cm}^{2}\right)$ & 0.813 & 0.109 & 0.650 to 1.064 \\
\hline Femoral neck $Z$ score & -0.2786 & 0.973 & -1.8 to 2.0 \\
\hline Total hip BMD $\left(\mathrm{g} / \mathrm{cm}^{2}\right)$ & 0.884 & 0.104 & 0.712 to 1.154 \\
\hline Total hip Z score & -0.4071 & 0.882 & -1.8 to 1.8 \\
\hline Serum Ca-corrected (mmol/l) & $2 \cdot 23$ & 0.51 & 2.13 to 2.31 \\
\hline Serum ionised $\mathrm{Ca}(\mathrm{mmol} / \mathrm{l})(n 13)$ & $1 \cdot 12$ & 0.02 & 1.09 to 1.16 \\
\hline Urinary Ca:creatinine ratio & 0.2306 & 0.102 & 0.0333 to 0.4800 \\
\hline Serum 25(OH)D (nmol/l) & $43 \cdot 6$ & $18 \cdot 9$ & 14.0 to 99.0 \\
\hline Parathyroid hormone (pmol/l) & 4.519 & $1 \cdot 216$ & 2.43 to 7.33 \\
\hline Serum P $(\mathrm{mmol} / \mathrm{l})$ & 1.256 & 0.086 & 1.080 to 1.430 \\
\hline CTx $(\mu \mathrm{g} / \mathrm{l})$ & 0.362 & 0.119 & 0.123 to 0.753 \\
\hline
\end{tabular}

BMD, bone mineral density; 25(OH)D, 25-dihydroxyvitamin D; CTx, C-telopeptide of type I collagen.

Table 3. Dietary nutrient intake from $3 \mathrm{~d}$ food diaries (Mean values, standard deviations and ranges; $n$ 28)

\begin{tabular}{lccc}
\hline & Mean & SD & Range \\
\hline Total energy (kJ) & 5909 & 1748 & $3002-10329$ \\
Carbohydrate $(\mathrm{g})$ & $159 \cdot 3$ & 54.9 & $78 \cdot 7-267 \cdot 3$ \\
Protein $(\mathrm{g})$ & $71 \cdot 2$ & $23 \cdot 7$ & $27 \cdot 1-118 \cdot 0$ \\
Total fat $(\mathrm{g})$ & $55 \cdot 7$ & $24 \cdot 8$ & $17 \cdot 0-133 \cdot 4$ \\
$\mathrm{Ca}(\mathrm{mg})$ & 587 & 335 & $189-1440$ \\
Mg $(\mathrm{mg})$ & 234 & 97 & $86-451$ \\
$\mathrm{P}(\mathrm{mg})$ & 1040 & 387 & $359-1694$ \\
\hline
\end{tabular}

consumption (Fig. 1(A)). There was a significant difference in serum $\mathrm{Ca}$ concentration between the $250 \mathrm{mg}$ dose and the $1000 \mathrm{mg}$ dose from time point $2 \mathrm{~h}$ to $5 \mathrm{~h}$. At time point 3 $\mathrm{h}$, serum Ca was significantly higher for the $1000 \mathrm{mg}$ dose compared with the $500 \mathrm{mg}$ dose. Between 3 and $4 \mathrm{~h}$ serum $\mathrm{Ca}$ reached a plateau when the 1000 and $500 \mathrm{mg}$ drinks were consumed, but began to decline after the fourth hour. However, following consumption of the $250 \mathrm{mg}$ drink, serum $\mathrm{Ca}$ began to decline from the third hour. There was a significant difference in the integrated responses (AUC) for serum $\mathrm{Ca}$ between the 250 and $500 \mathrm{mg}$ loads $(P=0 \cdot 01)$, the 500 and $1000 \mathrm{mg}(P=0.003)$ and between the 250 and $1000 \mathrm{mg}(P<0 \cdot 001)$ loads (Fig. 1(B)).

Serum ionised $\mathrm{Ca}$ was measured in a subset of thirteen subjects. There was no significant difference at any one time between the three milk drinks (Fig. 2). However, there was a trend for the AUC for the $250 \mathrm{mg}$ drink to be less than for the $500 \mathrm{mg}$ drink $(P=0 \cdot 064)$ (data not shown).

\section{Parathyroid hormone}

There were significant treatment $(P<0 \cdot 001)$ as well as time $(P$ $<0.001)$ effects on the PTH levels, but the interaction was borderline significant $(P=0 \cdot 068)$. Serum PTH concentration decreased markedly between baseline and $1 \mathrm{~h}$ in response to
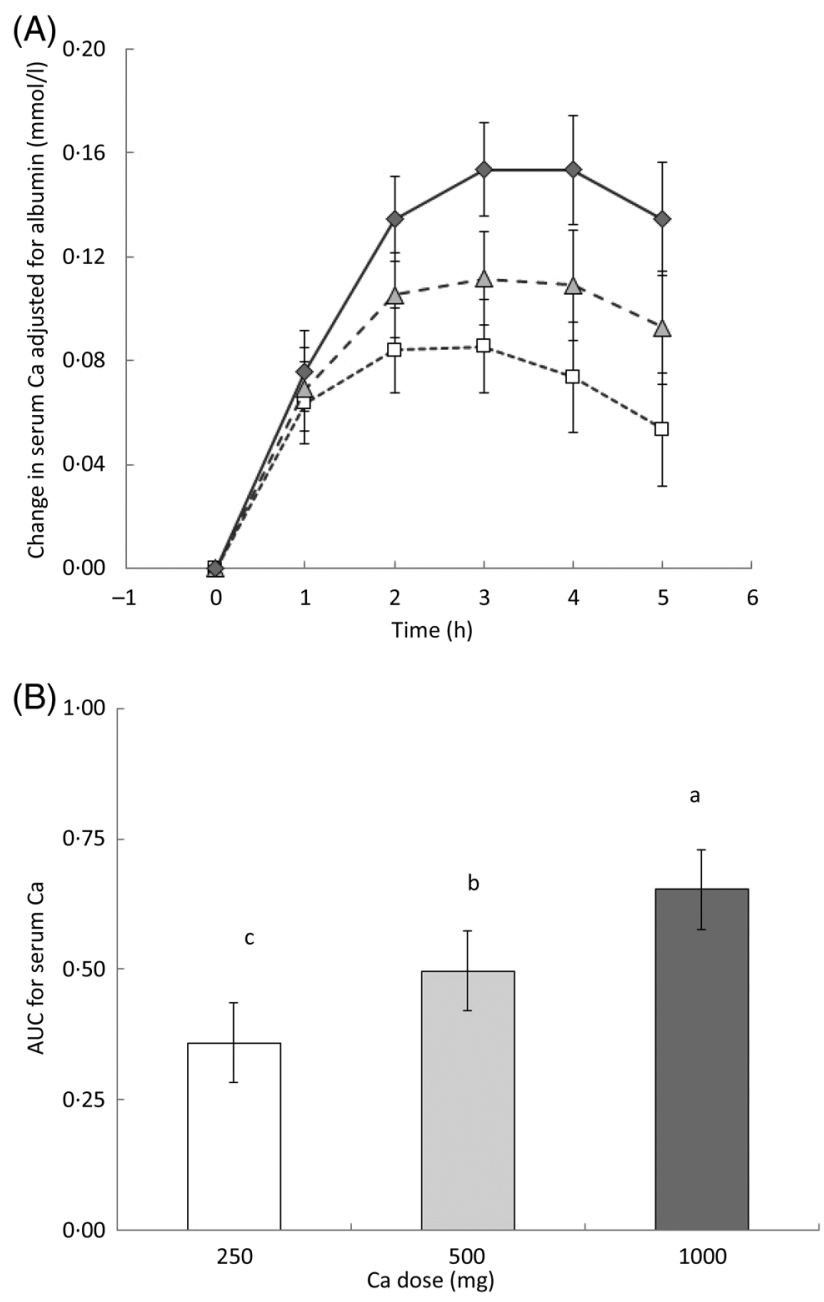

Fig. 1. (A) Change in serum calcium adjusted for albumin from baseline over time for each milk drink: $250 \mathrm{mg}$ dose $(\square) ; 500 \mathrm{mg}$ dose $(\triangle) ; 1000 \mathrm{mg}$ dose $(\diamond)$. Values are means, with $95 \% \mathrm{Cl}$ represented by vertical bars. There was an effect of drink $\times$ time $(P=0.005)$. (B) AUC for serum calcium concentration over the $5 \mathrm{~h}$ period. Values are means, with $95 \% \mathrm{Cl}$ represented by vertical bars. ${ }^{a, b, c}$ Mean values with unlike letters were significantly different $(P<0.001)$. 


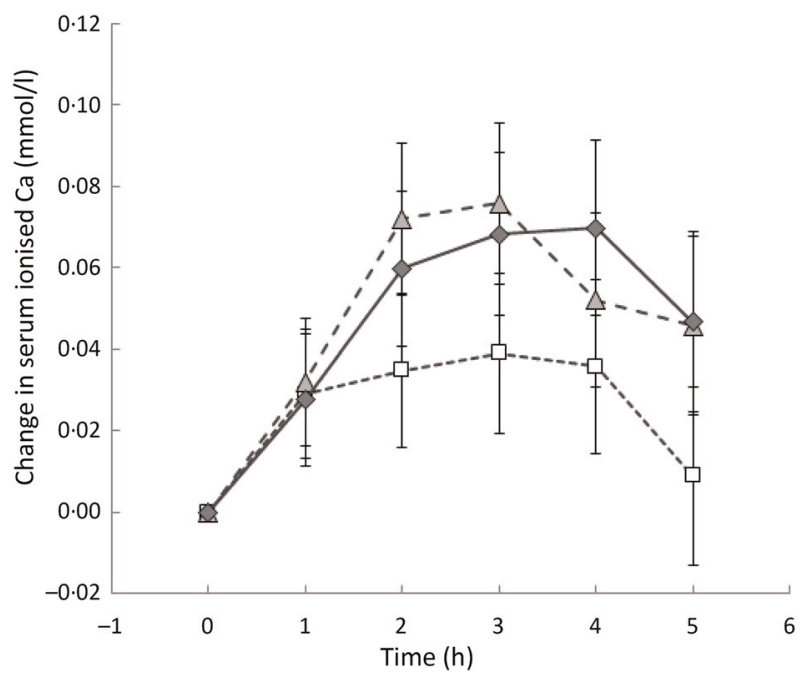

Fig. 2. Change in serum ionised calcium from baseline over time for each milk drink: $250 \mathrm{mg}$ dose $(\square) ; 500 \mathrm{mg}$ dose $(\triangle) ; 1000 \mathrm{mg}$ dose $(\diamond)$. Values are means, with $95 \% \mathrm{Cl}$ represented by vertical bars.
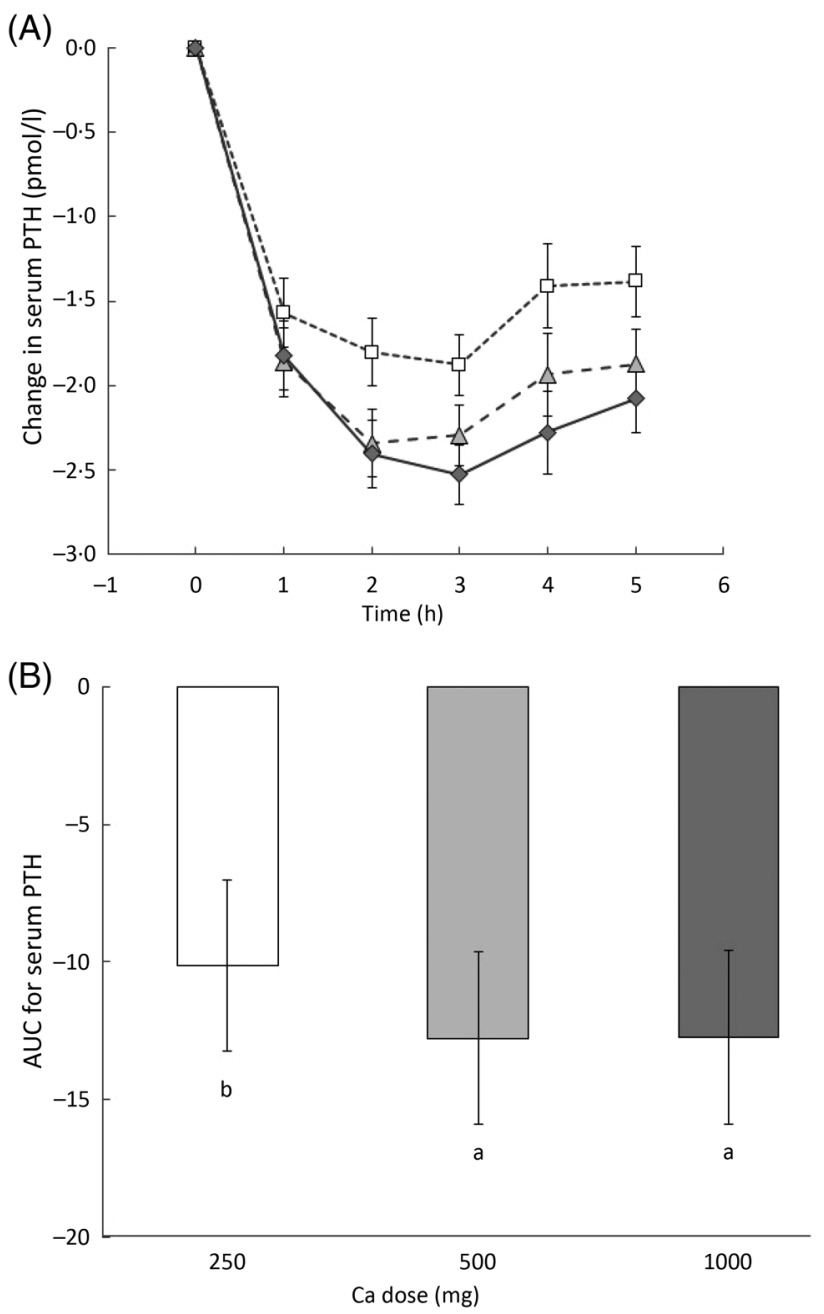

Fig. 3. (A) Change in serum parathyroid hormone (PTH) from baseline over time for each milk drink: $250 \mathrm{mg}$ dose $(\square) ; 500 \mathrm{mg}$ dose $(\triangle) ; 1000 \mathrm{mg}$ dose $(\diamond)$. Values are means, with $95 \% \mathrm{Cl}$ represented by vertical bars. (B) AUC for change in serum PTH from baseline to end point. Values are means, with $95 \% \mathrm{Cl}$ represented by vertical bars. ${ }^{\mathrm{a}, \mathrm{b}}$ Mean values with unlike letters were significantly different $(P<0.001)$.
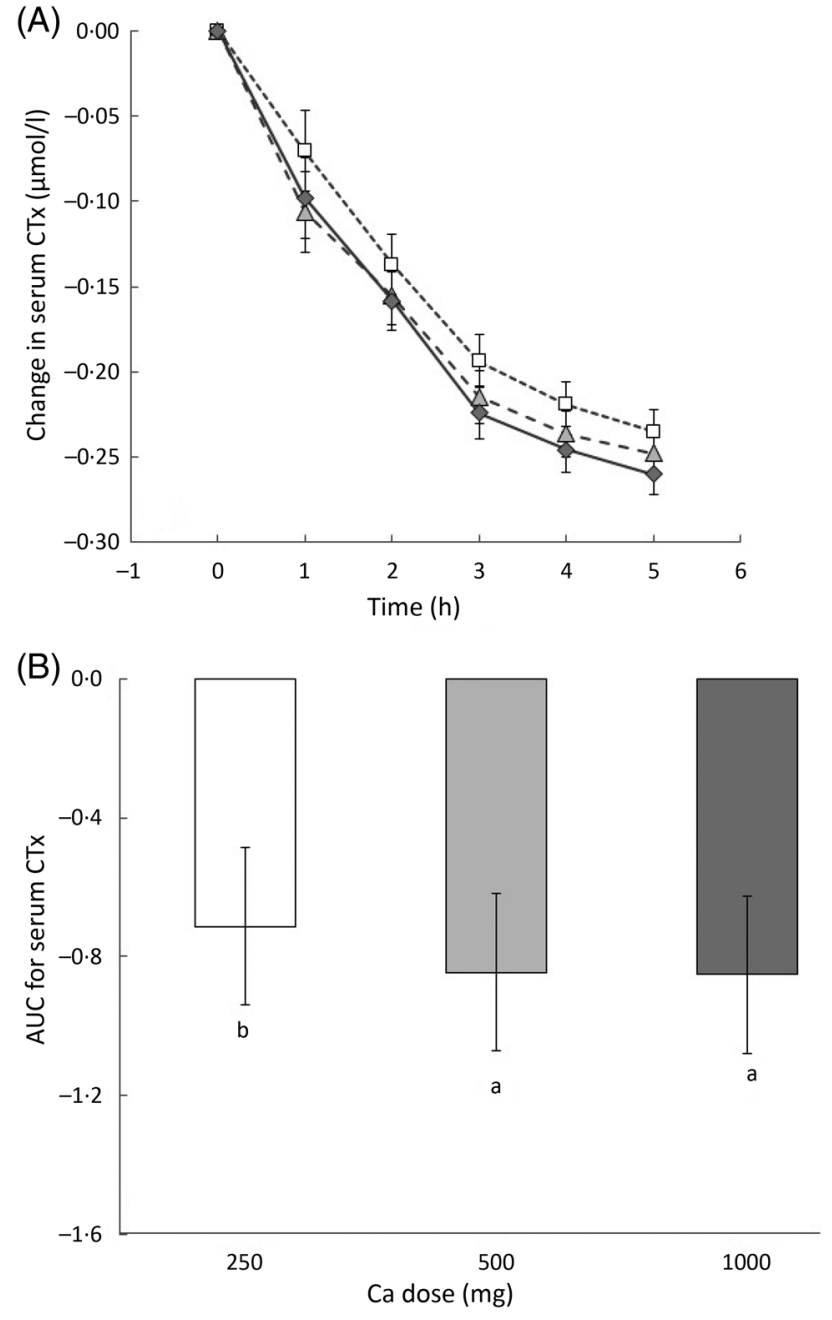

Fig. 4. (A) Change in serum C-telopeptide of type I collagen (CTx) over time for each milk drink: $250 \mathrm{mg}$ dose $(\square) ; 500 \mathrm{mg}$ dose $(\triangle) ; 1000 \mathrm{mg}$ dose $(\diamond)$. Values are means, with $95 \% \mathrm{Cl}$ represented by vertical bars. (B) AUC for change in serum CTx from baseline to end point. Values are means, with 95 $\% \mathrm{Cl}$ represented by vertical bars. ${ }^{\mathrm{a}, \mathrm{b}}$ Mean values with unlike letters were significantly different $(P=0.001)$.

all the milk drinks. From 2 to $5 \mathrm{~h}$, PTH concentrations remained significantly lower in response to the 500 and $1000 \mathrm{mg}$ drinks compared with the $250 \mathrm{mg}$ drink (Fig. 3(A)). There was a significant difference in the integrated responses between the 250 and the $500 \mathrm{mg}(P<0.001)$ as well as between the 250 and the $1000 \mathrm{mg}$ dose $(P<0.001)$ (Fig. 3 (B)). There was no significant difference between the integrated responses to the $500 \mathrm{v}$. the $1000 \mathrm{mg}$ dose.

\section{Serum C-telopeptide of type I collagen}

There were significant treatment and time effects on CTx levels but no significant interaction between these. Serum CTx levels decreased steadily from baseline throughout the $5 \mathrm{~h}$ of the trial (Fig. $4(\mathrm{~A})$ ). From time point 4 and $5 \mathrm{~h}$, there was a significant difference between changes in CTx for the $250 v$. the $1000 \mathrm{mg}$ dose $(P=0 \cdot 002)$. There was significant difference in the integrated response between the $250 \mathrm{mg}$ dose and the $500 \mathrm{mg}$ as well as the $1000 \mathrm{mg}$ dose $(P<0 \cdot 001)$ (Fig. 4(B)). 

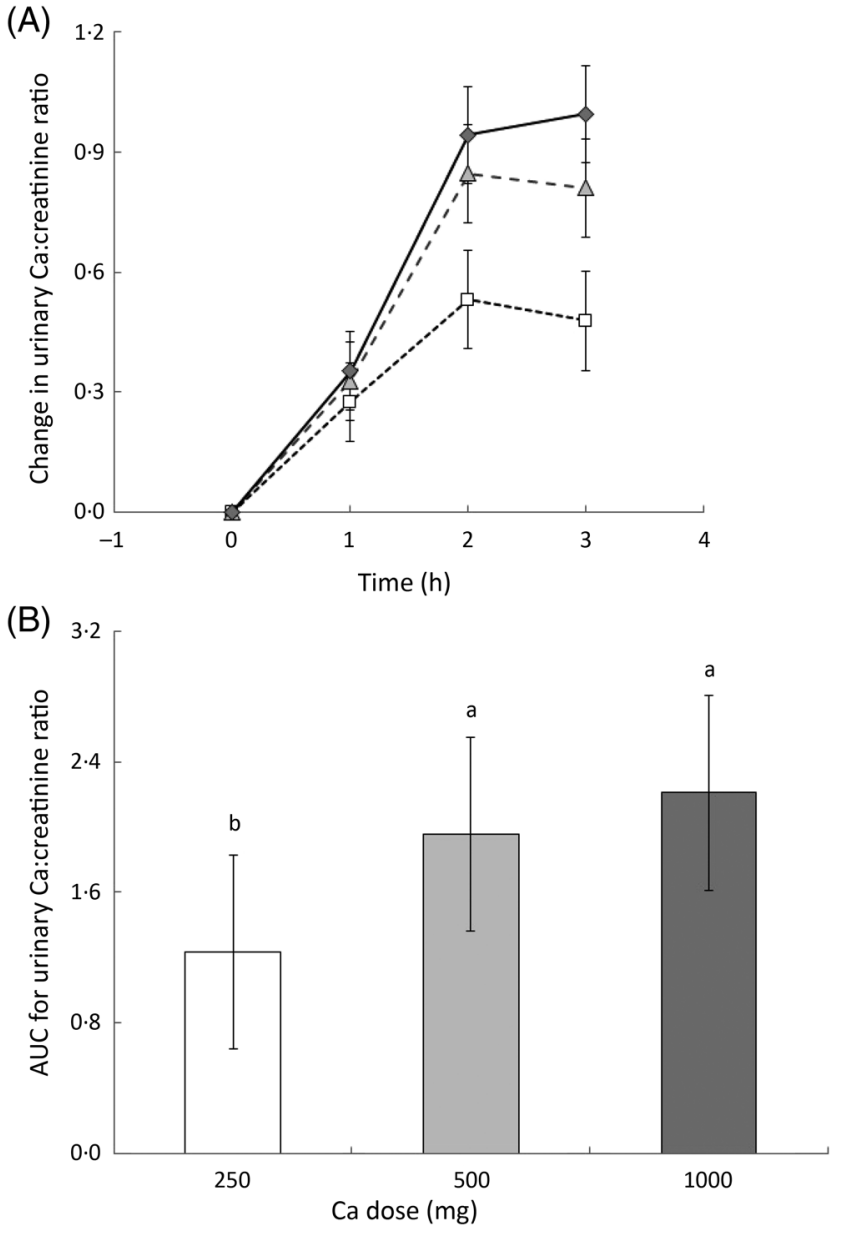

Fig. 5. (A) Urinary calcium:creatinine ratio differences from baseline as measured at three time points during $6 \mathrm{~h}$ for each milk drink: $250 \mathrm{mg}$ dose ( $\square$ ); 500 $\mathrm{mg}$ dose $(\triangle) ; 1000 \mathrm{mg}$ dose $(\diamond)$. Values are means, with $95 \% \mathrm{Cl}$ represented by vertical bars. (B) AUC for change in urinary calcium:creatinine ratio from baseline to end point. Values are means, with $95 \% \mathrm{Cl}$ represented by vertical bars. ${ }^{a, b}$ Mean values with unlike letters were significantly different $(P<0.021)$.

\section{Urinary calcium}

Urinary Ca excretion was measured at baseline and then in $2 \mathrm{~h}$ intervals and is reported as the urinary Ca:creatinine ratio. Urinary $\mathrm{Ca}$ in relation to creatinine increased 2 -fold in the first $2 \mathrm{~h}$ following consumption of all the milk drinks. By the second urine collection at $4 \mathrm{~h}$, the ratio was significantly greater $(P<0.001)$ following consumption of the 500 and $1000 \mathrm{mg}$ drinks than following the $250 \mathrm{mg}$ drink (Fig. 5(A)). At the final urine collection $(6 \mathrm{~h})$ the ratio was decreasing in response to the 250 and $500 \mathrm{mg}$ drinks, but continuing to increase in response to the $1000 \mathrm{mg}$ drink. At this time point the ratio was still significantly higher following the 500 and $1000 \mathrm{mg}$ drinks compared with following the $250 \mathrm{mg}$ drink.

There was significant difference in the integrated response between the $250 \mathrm{mg}$ dose and the $500 \mathrm{mg}$ as well as the $1000 \mathrm{mg}$ dose $(P<0.021)$ (Fig. 5(B)).

Comparison of the response to $1000 \mathrm{mg}$ Ca in milk $v$. the Ca salt showed no difference in serum corrected or ionised $\mathrm{Ca}, \mathrm{CTx}$ or urinary Ca:creatinine ratio. For serum ionised Ca and $\mathrm{PTH}$, there were interactions between treatment and
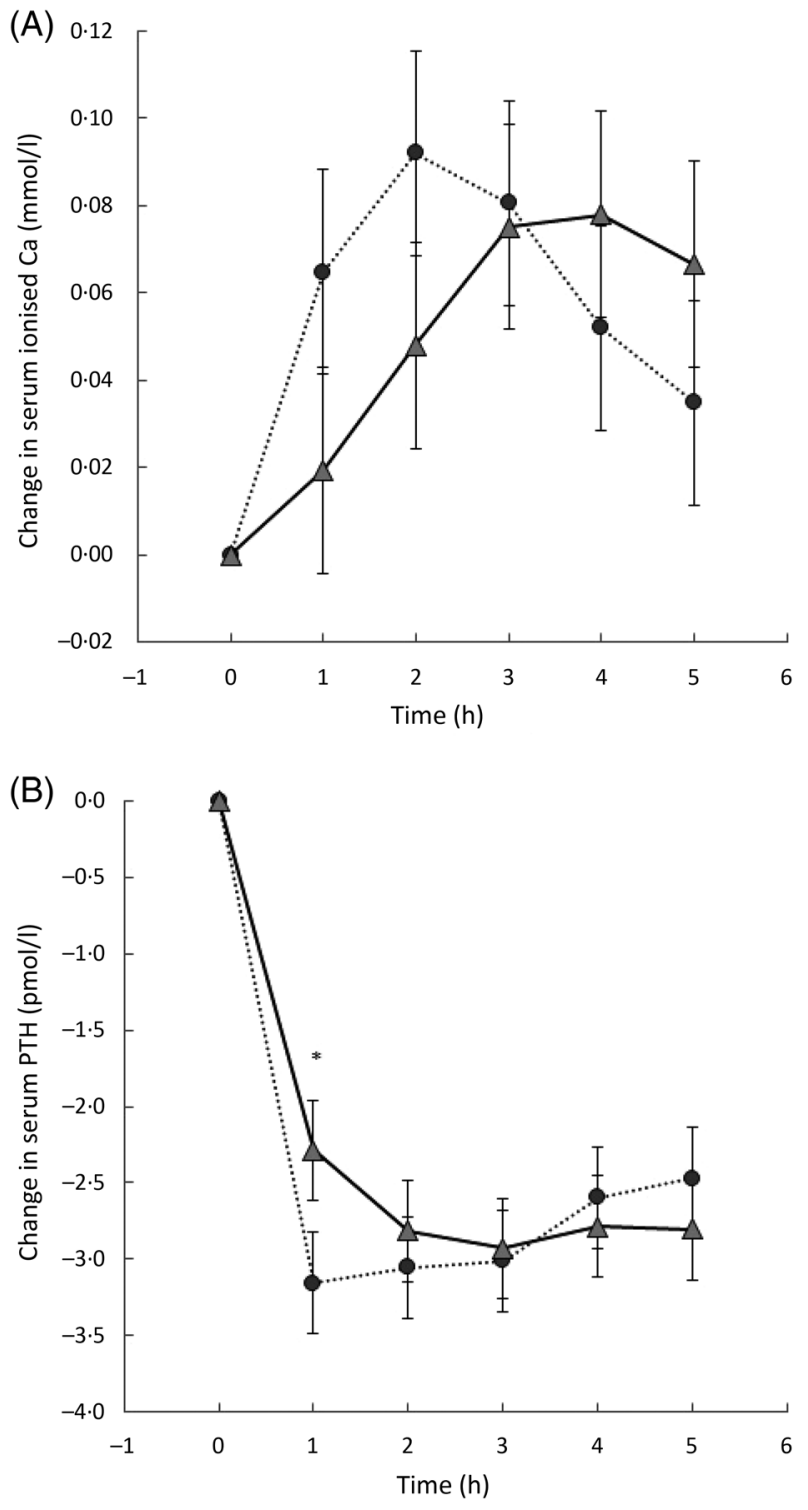

Fig. 6. (A) Change in serum ionised calcium from baseline over time for the tablet containing $1000 \mathrm{mg}$ calcium (•) or the milk delivering $1000 \mathrm{mg}$ calcium $(\triangle)$. Values are means, with $95 \% \mathrm{Cl}$ represented by vertical bars. (B) Change in serum parathyroid hormone (PTH) levels over time after a dose of $1000 \mathrm{mg}$ as the salt $(\bullet)$ or in milk $(\triangle)$. Values are means, with $95 \% \mathrm{Cl}$ represented by vertical bars. * Mean value was significantly different from that for the salt $(P<0.05)$.

time, but no overall treatment effect and no effect on AUC. This indicates that there were no differences in the total levels for PTH or Ca measured, but the patterns of appearance/disappearance in the blood over time were different for the two treatments. After the oral dose of the Ca salt, ionised Ca increased faster, reached its peak earlier and decreased sooner and faster than with the Ca dose in milk (Fig. 6(A)). With the dose of Ca salt, serum PTH decreased faster and reached a plateau earlier when compared with the milk group (Fig. 6(B)).

\section{Discussion}

The aim of the present study was to assess the physiological response to three doses of $\mathrm{Ca}$ delivered in milk, as well as comparing the response to a $\mathrm{Ca}$ salt in water. The data 
presented show that there is a graded physiological response in total blood $\mathrm{Ca}$ concentration depending on the dose of $\mathrm{Ca}$ taken. A similar dose of $\mathrm{Ca}$ as the salt compared with the dose in milk resulted in a faster rise in ionised $\mathrm{Ca}$ in the blood. The peak concentration was reached earlier and the blood levels decreased earlier compared with a Ca dose in milk. As serum Ca increased, PTH responded in an inverse manner, reaching the lowest level after $3 \mathrm{~h}$ and then beginning to increase again. The largest response was to the dose of $1000 \mathrm{mg} \mathrm{Ca}$ in milk, with a lower response to $500 \mathrm{mg}$ and a significantly lower response to $250 \mathrm{mg}$. Serum CTx levels decreased steadily over the $5 \mathrm{~h}$ with a significant difference between the response to $250 \mathrm{mg}$ and those to 500 or 1000 $\mathrm{mg}$ in milk, while there was no difference in the response to $1000 \mathrm{mg} \mathrm{Ca}$ as the salt or in milk.

Ca supplementation has been shown in several short- and long-term studies to slow age-related bone loss and to reduce the risk of hip fracture in older men and women. The absorption efficiency of the $\mathrm{Ca}$ is important for the beneficial effects on bone. A number of studies have been reported that compared various $\mathrm{Ca}$ formulations containing different salts, in short acute absorption trials as well as longer supplementation trials $^{(1-3,14,20)}$. The data from the acute trials report a rapid increase in serum ionised as well as corrected $\mathrm{Ca}$ after an oral dose. The response varies according to type of salt used $^{(2,9,21-23)}$ as well as the dose of the salt ${ }^{(1,9,24)}$. Guillemant \& Guillemant ${ }^{(1)}$ reported that the change in ionised Ca after a $1500 \mathrm{mg}$ dose of Ca from calcium gluconate/carbonate was significantly higher than when compared with a dose of $500 \mathrm{mg}$ while Zikán et al. ${ }^{(24)}$ reported a more prolonged increase in ionised Ca after a load of $1 \mathrm{~g} v$. a load of $0 \cdot 2 \mathrm{~g}$ elemental Ca.

When a food or milk is used as the vehicle for delivering the $\mathrm{Ca}$, the pattern of absorption may be different from the responses reported with a $\mathrm{Ca}$ salt using water as the carrier. The absorption of similar levels of Ca from Emmental cheese, milk and spinach was slower compared with the response to calcium lactate gluconate, and serum ionised $\mathrm{Ca}$ did not reach the same maximal concentration, although the serum ionised $\mathrm{Ca}$ response after consuming cheese almost reached a similar level to that of the Ca salt, though with a $2 \mathrm{~h}$ delay ${ }^{(14)}$. In contrast, Nickel et al. ${ }^{(25)}$ reported that fractional absorption of $\mathrm{Ca}$ from various dairy products was similar, and Martini \& $\operatorname{Wood}^{(26)}$ reported that a dose of $500 \mathrm{mg} \mathrm{Ca}$ from Ca-fortified orange juice, skimmed milk and calcium carbonate did not result in significantly different serum levels of $\mathrm{Ca}$. The acute response to a dose of calcium carbonate or milk $\mathrm{Ca}$ in milk as the carrier did, however, elicit a different response, with calcium carbonate raising blood Ca significantly more compared with milk $\mathrm{Ca}^{(11)}$. Comparing regular milk with milk Ca- or tricalcium phosphate-fortified milk, increased absorption of $\mathrm{Ca}$ from the fortified milks using stable isotopes was demonstrated ${ }^{(27)}$. No other investigations could be found where different doses of $\mathrm{Ca}$ in milk were compared with each other in the same study. In addition, the present study also showed that the response to a load of $\mathrm{Ca}$ from a salt is faster, increasing serum and ionised $\mathrm{Ca}$ more rapidly but reaching a plateau quicker, compared with the same dose in milk, in accordance with Green et $a l^{(15)}$ and López-Huertas et al. ${ }^{(27)}$.

The three doses of $\mathrm{Ca}$ in milk suppressed serum PTH in a dose-dependent manner but the responses to the 500 and the $1000 \mathrm{mg}$ Ca doses were not significantly different. The suppression of PTH by $\mathrm{Ca}$ is a response to maintain $\mathrm{Ca}$ homeostasis, and is mediated by the Ca-sensing receptor in the parathyroid gland. This receptor responds to the transient increase in plasma ionised $\mathrm{Ca}$ within seconds. Several authors have reported the Ca-dependent postprandial decrease in PTH $^{(1,3,11,13,14,26,28)}$ and also reported a dose-dependent response ${ }^{(14,23)}$ using a variety of foods depending on the bioavailability of $\mathrm{Ca}$ from the foods. No reports could be found where the response to various doses of $\mathrm{Ca}$ in the same food, or from milk, was compared. In the present study the serum PTH concentration decreased in parallel with the increase in serum and ionised $\mathrm{Ca}$ concentrations, the latter affected by the dose-dependent absorption of $\mathrm{Ca}$ in the intestine. We did not show a significant difference in the ionised Ca concentration between the various doses but there was a trend for the response after the $250 \mathrm{mg}$ dose to be lower than the response to the 500 and $1000 \mathrm{mg}$ dose. Accordingly, the response by serum PTH was significantly higher for the 500 and 1000 $\mathrm{mg}$ doses of Ca compared with the $250 \mathrm{mg}$ dose.

Serum CTx levels decreased from baseline over the $5 \mathrm{~h}$ of sampling, and did not reach a plateau by $5 \mathrm{~h}$. The response to the $250 \mathrm{mg}$ dose was significantly less than the response to the 500 and $1000 \mathrm{mg}$ doses between time points 4 and $5 \mathrm{~h}$ but all three doses significantly decreased CTx. The reduction in PTH over time suggested that bone remodelling was being suppressed by the various doses of $\mathrm{Ca}$ and this was confirmed by the reduction in CTx. PTH decreased rapidly after the dose of $\mathrm{Ca}$, reaching a minimum value by $3 \mathrm{~h}$. In contrast, the response by CTx was slower, and more continuous, and was still strongly suppressed at $5 \mathrm{~h}$ after the $\mathrm{Ca}$ dose. The delay in response by CTx to a Ca load was also reported by Zikán et al. ${ }^{(24)}$ in young women and by Green et al. ${ }^{(11,15)}$ and Martini \& Wood $^{(26)}$ in postmenopausal women. The immediate response of PTH to a Ca load may therefore lead to the reduction in CTx as well, albeit slower, suggesting that the suppression of bone resorption may last longer than the actual decrease in serum PTH levels. The osteoclast has also been shown to have Ca-sensing receptors ${ }^{(24)}$, and $\mathrm{Ca}$ ions may therefore directly regulate bone resorption. The response of the osteoclast may, however, only occur at higher extracellular Ca concentrations ${ }^{(24)}$. The osteocyte is able to regulate small changes in serum $\mathrm{Ca}$ by the process of osteocytic osteolysis. This process does not involve bone resorption but only movement of $\mathrm{Ca}$ controlled by the osteocyte. This process, however, is short; response is within 1-3 h after a change in serum $\mathrm{Ca}$ and does not affect bone resorption and would not elicit a response by PTH or CTx ${ }^{(29)}$.

In a controlled situation there is a strong correlation between acute intake of $\mathrm{Ca}$ and urinary $\mathrm{Ca}$ excretion. The excretion of $\mathrm{Ca}$ increased as the dose of $\mathrm{Ca}$ in milk increased, but the change in excretion was not significantly different between the $500 \mathrm{mg}$ and the $1000 \mathrm{mg}$ dose, while both of these were significantly higher than the excretion after the $250 \mathrm{mg}$ dose. There was, 
however, a significant difference in the integrated response between the three doses from milk (Fig. 3(B)). Urinary Ca usually changes according to the amount and bioavailability of the Ca load, whether from food or a salt. When we compared the urinary excretion of $\mathrm{Ca}$ after the $1000 \mathrm{mg}$ load from milk or the salt, there was no significant difference, which indicates that $\mathrm{Ca}$ was absorbed equally well from both forms of Ca. Kärkkäinen et al. ${ }^{(14)}$ reported increased urinary Ca excretion after a $400 \mathrm{mg}$ dose of $\mathrm{Ca}$ as the salt compared with the same dose in milk. Green $e t a l^{(11)}$ reported no significant difference in urinary $\mathrm{Ca}$ excretion between milk fortified with milk $\mathrm{Ca}$ or calcium carbonate, and Martini \& Wood ${ }^{(26)}$ reported no significant effect of Ca source on urinary $\mathrm{Ca}$ excretion using a similar load of $\mathrm{Ca}$ in orange juice, milk or as a salt in water. The above data therefore suggest that urinary $\mathrm{Ca}$ excretion is a function of $\mathrm{Ca}$ load and not sensitive to whether the $\mathrm{Ca}$ is provided as a salt or in a food. The kind of salt, however, may affect absorption and excretion with the lactate gluconate salt of $\mathrm{Ca}$ being more soluble, more absorbable and resulting in higher excretion compared with calcium carbonate or Ca from fortified milk ${ }^{(2,14)}$.

Ca supplements are widely used for the prevention or treatment of osteoporosis in postmenopausal women. However, some concern has been raised about the safety of using $\mathrm{Ca}$ supplements, as trials in healthy older women and in patients with renal impairment suggest that $\mathrm{Ca}$ supplementation may increase the risk of myocardial infarction, stroke and overall CVD $^{(13,30-32)}$. Although this association remains controversial and the analyses have been strongly criticised, it has been hypothesised that a potential mechanism may involve the significant rise in serum ionised $\mathrm{Ca}$ (to the upper part - or over the normal range) that has been shown after a $1 \mathrm{~g}$ dose of $\mathrm{Ca}$ by Karp et al. ${ }^{(2)}$ and others ${ }^{(13,22,30)}$. The possibility exists that the higher circulating ionised $\mathrm{Ca}$ concentrations may affect vascular calcification, the function of the vascular cells and blood coagulation ${ }^{(30-32)}$.

The response in serum and ionised $\mathrm{Ca}$ to a $\mathrm{Ca}$ load over time has been shown to be different between $\mathrm{Ca}$ consumed in milk and that consumed as a $\mathrm{Ca}$ salt. The change in serum ionised $\mathrm{Ca}$ after a dose of a $\mathrm{Ca}$ salt was shown to be markedly higher $(0.09 v .0 .075 \mathrm{mmol} / \mathrm{l})$ and faster (peak at $2 \mathrm{~h} v$ at $3 \cdot 5-4 \mathrm{~h}$ ) than the response to a similar dose of $\mathrm{Ca}$ in milk. In the present study we therefore have confirmed that the response in ionised $\mathrm{Ca}$ to a $1 \mathrm{~g}$ dose of $\mathrm{Ca}$ salt and $1 \mathrm{~g} \mathrm{Ca}$ in milk is different.

In conclusion, the present data support the notion that the postprandial response to $\mathrm{Ca}$ from foods is different from that from a $\mathrm{Ca}$ salt, and that fortified milk can deliver relatively large doses of $\mathrm{Ca}$ without perturbing $\mathrm{Ca}$ homeostasis. This trial was done in young Asian women and the response to a load of $\mathrm{Ca}$ in this population may differ from that of older or postmenopausal women in other populations. The results should therefore be extrapolated with caution.

\section{Acknowledgements}

The authors gratefully acknowledge the support of Regina Wypych for trial coordination and Maria-Tine Biersteker and Simon Bennett for blood sampling and processing.
Fonterra Brands Singapore Ltd funded the study. The funder had no role in the design, analysis or writing of this article.

M. C. K. was primary investigator; M. C. K. and L. M. S. designed the research; P. v. H. and C. L. B. conducted the research; B. K.-S. performed statistical analyses; M. C. K., J. M. T. and L. M. S. drafted the manuscript; M. C. K. had primary responsibility for the final content. All authors read and approved the final manuscript.

M. C. K., P. v. H. and C. L. B. declare no conflict of interest. L. M. S. and B. K.-S. are employees of Fonterra Research and Development Centre. J. M. T. is an employee of Fonterra Cooperative Group Ltd.

\section{References}

1. Guillemant J \& Guillemant S (1993) Comparison of the suppressive effect of two doses $(500 \mathrm{mg}$ vs $1500 \mathrm{mg}$ ) of oral calcium and parathyroid hormone secretion and on urinary cyclic AMP. Calcif Tissue Int 53, 304-306.

2. Karp HJ, Ketola ME \& Lamberg-Allardt (2009) Acute effects of calcium carbonate, calcium citrate and potassium citrate on markers of calcium and bone metabolism in young women. Br J Nutr 102, 1341-1347.

3. Sadideen H \& Swaminathan R (2004) Effect of acute oral calcium load on serum PTH and bone resorption in young healthy subjects: an overnight study. Eur J Clin Nutr 58, 1661-1665.

4. Yang R-S, Liu T-K \& Tsai K-S (1994) The acute metabolic effects of oral tricalcium phosphate and calcium carbonate. Calcif Tissue Int 55, 335-341.

5. Heaney RP, Weaver CM, Fitzsimmons ML, et al. (1990) Calcium absorptive consistency. J Bone Miner Res 5, 1139-1142.

6. Heaney RP, Weaver CM \& Fitzsimmons ML (1990) Influence of calcium load on absorption fraction. J Bone Miner Res 5, 1135-1138.

7. Heaney RP, Berner B \& Louie-Helm J (2000) Dosing regimen for calcium supplementation. J Bone Miner Res 15, 2291.

8. Heaney RP, Saville PD \& Recker RR (1975) Calcium absorption as a function of calcium intake. J Lab Clin Med 85, 881-890.

9. Harvey JA, Zobitz MM \& Pak CYC (1988) Dose dependency of calcium absorption: a comparison of calcium carbonate and calcium citrate. J Bone Miner Res 3, 253-258.

10. Käkkäinem MUM, Lamberg-Allardt CJE, Ahonen S, et al. (2001) Does it make a difference how and when you take your calcium? The acute effects of calcium and bone metabolism. Am J Clin Nutr 74, 335-342.

11. Green JH, Booth C \& Bunning R (2003) Postprandial metabolic responses to milk enriched with milk calcium are different from responses to milk enriched with calcium carbonate. Asia Pac J Clin Nutr 12, 109-119.

12. Recker RR \& Heaney RP (1985) The effect of milk supplements on calcium metabolism, bone metabolism and calcium balance. Am J Clin Nutr 41, 254-263.

13. Reid IR, Bolland MJ \& Grey A (2010) Does calcium supplementation increase cardiovascular risk? Clin Endocrinol (Oxf) 73, 689-695.

14. Kärkkäinem MUM, Wiersma JW \& Lamberg-Allardt CJE (1997) Postprandial parathyroid hormone response to four calcium-rich foodstuffs. Am J Clin Nutr 65, 1726-1730.

15. Green JH, Booth C \& Bunning R (2003) Acute effect of highcalcium milk with or without additional magnesium, or calcium phosphate on parathyroid hormone and biochemical markers of bone resorption. Eur J Clin Nutr 57, 61-68.

16. Heaney RP, McCarron DA, Dawson-Hughes B, et al. (1999) Dietary changes favourably affect bone remodelling in older adults. J Am Diet Assoc 99, 1228-1233.

17. Kruger MC, Schollum LM, Kuhn-Sherlock B, et al. (2006) Effect of calcium fortified milk supplementation with or without vitamin $\mathrm{K}$ 
on biochemical markers of bone turnover in premenopausal women. Nutrition 22, 1120-1128.

18. Kruger MC, Schollum LM, Kuhn-Sherlock B, et al. (2010) The effect of a fortified milk drink on vitamin D status and bone turnover in post-menopausal women from South East Asia. Bone 46, 759-767.

19. Maunsell Z, Wright DJ \& Rainbow SJ (2005) Routine isotopedilution liquid chromatography-tandem mass spectrometry assay for simultaneous measurement of 25-hydroxy metabolites of vitamins $\mathrm{D}_{2}$ and $\mathrm{D}_{3}$. Clin Chem 51, 1683-1690.

20. Horowitz M, Morris HA, Hartley TF, et al. (1987) The effect of an oral calcium load on plasma ionized calcium and parathyroid hormone concentrations in osteoporotic postmenopausal women. Calcif Tissue Int 40, 133-136.

21. Heaney RP, Dowell MS, Bierman J, et al. (2001) Absorbability and cost effectiveness in calcium supplementation. J Am Coll Nutr 20, 239-246.

22. Reid IR, Hannan SF, Schooler BA, et al. (1986) The acute biochemical effects of four proprietary calcium preparations. Aust NZ J Med 16, 193-197.

23. Talbot JR, Guardo P, Seccia S, et al. (1999) Calcium bioavailability and parathyroid hormone acute changes after oral intake of dairy and nondairy products in healthy volunteers. Osteoporos Int 10, 137-142.

24. Zikán V, Haas T \& Stepan JJ (2001) Acute effects in healthy women of oral calcium on the calcium-parathyroid axis and bone resorption as assessed by serum $\beta$-CrossLaps. Calcif Tissue Int $\mathbf{6 8}$, 352-357.

25. Nickel KP, Martin BR, Smith DL, et al. (1996) Calcium bioavailability from bovine milk and dairy products in premenopausal women using intrinsic and extrinsic labelling techniques. J Nutr 126, 1406-1411.

26. Martini L \& Wood RJ (2002) Relative bioavailability of calcium-rich dietary sources in the elderly. Am J Clin Nutr 76, 1345-1350.

27. López-Huertas E, Teacher B, Boza JJ, et al. (2006) Absorption of calcium from milks enriched with fructo-oligosaccharides, caseinophosphopeptides, tricalcium phosphate, and milk solids. Am J Clin Nutr 83, 310-316.

28. Guillemant J, Le H-T, Maria A, et al. (2000) Acute effects of oral calcium load on parathyroid function and on bone resorption in young men. Am J Nephrology 20, 48-52.

29. Bonewald LF (2011) The amazing osteocyte. J Bone Miner Res 26, 229-238.

30. Reid IR, Bolland MJ, Avenell A, et al. (2011) Cardiovascular effects of calcium supplementation. Osteoporos Int 22, 1649-1658.

31. Bolland MJ, Barber PA, Doughty RN, et al. (2008) Vascular events in healthy older women receiving calcium supplementation: randomised controlled trial. BMJ 336, 262-266.

32. Bolland MJ, Avenell A, Baron JA, et al. (2010) Effect of calcium supplements on risk of myocardial infarction and cardiovascular events: meta-analysis. BMJ 341, c3691. 